\title{
Sweet chestnut (Castanea sativa Mill.) in Britain: its dendrochronological potential
}

\author{
Rob Jarman ${ }^{\mathrm{a}}$, Andy K. Moir ${ }^{\mathrm{b}, \mathrm{c}}$, Julia Webb ${ }^{\mathrm{a}}$, Frank M. Chambers ${ }^{\mathrm{a}}$ \\ ${ }^{a}$ Centre for Environmental Change and Quaternary Research, University of \\ Gloucestershire, Cheltenham, UK; ${ }^{b}$ Tree-Ring Services, Mitcheldean, UK; ${ }^{c}$ Institute \\ for the Environment, Brunel University, Uxbridge, London, UK
}

Corresponding author: Rob Jarman, Centre for Environmental Change and Quaternary Research, University of Gloucestershire, Francis Close Hall, Cheltenham, UK, GL50 4AZ. rjarman1@glos.ac.uk

Dr. Andy Moir, Tree-Ring Services, Oakraven Field Centre, Jubilee Road, Mitcheldean, Glos., UK, GL17 OEE. akmoir@ tree-ring.co.uk; www.tree-ring.co.uk Julia Webb, Centre for Environmental Change and Quaternary Research, University of Gloucestershire, Francis Close Hall, Cheltenham, UK, GL50 4AZ. jwebb@glos.ac.uk

Professor Frank M Chambers, Centre for Environmental Change and Quaternary Research, University of Gloucestershire, Francis Close Hall, Cheltenham, UK, GL50 4AZ. fchambers@glos.ac.uk 


\title{
Sweet chestnut (Castanea sativa Mill.) in Britain: its dendrochronological potential
}

\author{
In Britain, where sweet chestnut is classified as an archaeophyte of Roman \\ introduction, there are many ancient sweet chestnut trees and woodlands \\ significant for conservation, yet no dendrochronological assessment has been \\ made of them. This paper describes an attempt to assess the \\ dendrochronological potential of sweet chestnut wood. Eight sweet chestnut \\ trees (veteran trees in parkland and mature trees and coppice-grown stems in \\ woodland) from five sites in western England were sampled by coring living \\ wood and by cutting sections in fallen dead wood, to enable microscopic \\ analysis of growth ring parameters. Four trees from three sites were cross- \\ matched to form a 295-year chronology from AD 1716 to AD 2011. The \\ annual resolution of the chronology was confirmed by regional cross-dating \\ with oak reference chronologies. The ages for these chestnut trees range from \\ circa AD 1668 to AD 1940. It is concluded that oak reference chronologies can \\ be used to date sweet chestnut wood, with benefits for archaeological, historic \\ building and palaeoenvironmental assessments. The extraction of sawn \\ sections from dead veteran trees and their dendrochronological analysis \\ indicates a more reliable and benign approach to dating ancient trees in historic \\ landscapes compared with coring.
}

Keywords: sweet chestnut Castanea sativa; oak Quercus robur/Q. petraea; dendrochronology; veteran trees.

\section{Introduction}

Sweet chestnut (Castanea sativa Mill.) is considered native to southern and eastern Europe, based on pollen evidence (Huntley \& Birks, 1983, p. 162; Krebs et al., 2004) showing that sweet chestnut survived in Europe during the last glacial period in refugia in parts of Spain, Italy, Greece and Turkey and eastwards into the Caucasus. Genetic studies of sweet chestnut populations across Europe (Mattioni, Martin, 
Pollegioni, Cherubini, \& Villani, 2013) have indicated two geographical genetic origins - eastern Europe (Greek/Turkish) and western Europe (Italian/Spanish) - that correspond with the identified glacial refugia. Sweet chestnut was exploited for cultivation by the Ancient Greeks and the Romans and introduced extensively across Europe in the Medieval and Renaissance periods - see Conedera, Krebs, Tinner, Pradella, and Torriani (2004) and Squatriti (2013).

The early origins of sweet chestnut growing in Britain are uncertain, despite three centuries of speculation - see for example Evelyn (1706), Ducarel (1771), Reid (1899). At present, sweet chestnut is classified as an archaeophyte of Roman introduction that is not indigenous to Britain (Godwin, 1975, p. 277; Preston, Pearman, \& Dines, 2002, p. 130; Rackham, 2006, p. 370; Stace \& Crawley, 2015, p. 35): 'an honorary native' is how it is typically described.

In Britain there is a rich assemblage of ancient sweet chestnut trees, woodlands and coppices, growing in significant cultural landscapes - medieval deer parks, historic parks and gardens, ancient semi-natural woodland, pasture-woodland and on ancient boundaries. Many of these sites are now in urban or semi-rural environments such as town parks, country parks and golf courses, where veteran tree management and ancient woodland conservation pose specific issues for managers and arboriculturalists. Sweet chestnut is distributed across Britain but is very localised, dependent on geology and soil types that provide the acidic ( $\mathrm{pH} 4.5-5.5)$, sandy, well-drained substrates that sweet chestnut prefers (Braden \& Russell, 2001; Buckley \& Howell, 2004).

Assessment of individual sweet chestnut trees and coppice stools suggests that some may be between 500 and 1000 years old, based on girth and historical records. Old trees are usually hollow or have regrown from collapsed boughs: to date it has 
been impossible to age them from tree-ring analysis and so girth has been used to estimate age. The Ancient Tree Inventory for the UK (Woodland Trust, 2016 database accessed in May 2016) lists over eleven hundred sweet chestnut trees of more than six metres girth, with the largest single tree of $19.8 \mathrm{~m}$ girth.

In Britain, a few specimens of sweet chestnut wood/charcoal found in archaeological excavations have been growth-ring counted (for example Groves, 1993; Hillam, 1985; Museum of London Archaeology, 2011; Nayling, 1991), but no research on sweet chestnut dendrochronology in Britain has been published.

Sweet chestnut has previously been stated in the international literature to have some dendrochronological potential: Grissino-Mayer (1993) defined it as of 'minor importance', with a CDI (Cross-dating Index) Value of 1 (scale of 0 to 2). In continental Europe, research has established growth-ring chronologies for sweet chestnut (for example Mirchev, Lyubenova, Dimitrova, \& Bratanova-Doncheva, 2009; Romagnoli, Nocetti, Sarlatto, \& Evangelistella, 2004). Fonti, Cherubini, Rigling, Weber, and Biging (2006) analysed tree rings in sweet chestnut coppices in Switzerland and concluded that sweet chestnut is suitable for dendrochronology because the heartwood is resistant to decay and the sapwood is thin (usually $<5$ years), and that errors caused by missing rings should be limited to only a few years. However, some European researchers have opined that sweet chestnut is unsuitable for dendrochronological analysis, noting a range of constraints, including inherent wood structure (Schweingruber, 1993, p. 181); a tendency to radial and circumferential splits or star and ring shake (Spina \& Romagnoli, 2010); and a typically rapid growth rate, resulting in comparatively few rings for analysis, even in larger-dimensioned timbers (Romagnoli et al., 2004). 
This paper describes an experiment to assess the suitability of sweet chestnut trees growing in Britain for dendrochronological studies, by sampling sites in western England for a selection of veteran trees in parkland, mature standard trees in woodland and coppice-grown stems in woodland. The aim was not to try to develop sweet chestnut as a species for dendroclimatological studies. Rather, the objective was to find a method for dating veteran sweet chestnut trees and potentially also historic timbers in Britain, via cross-matching with oak reference chronologies. 


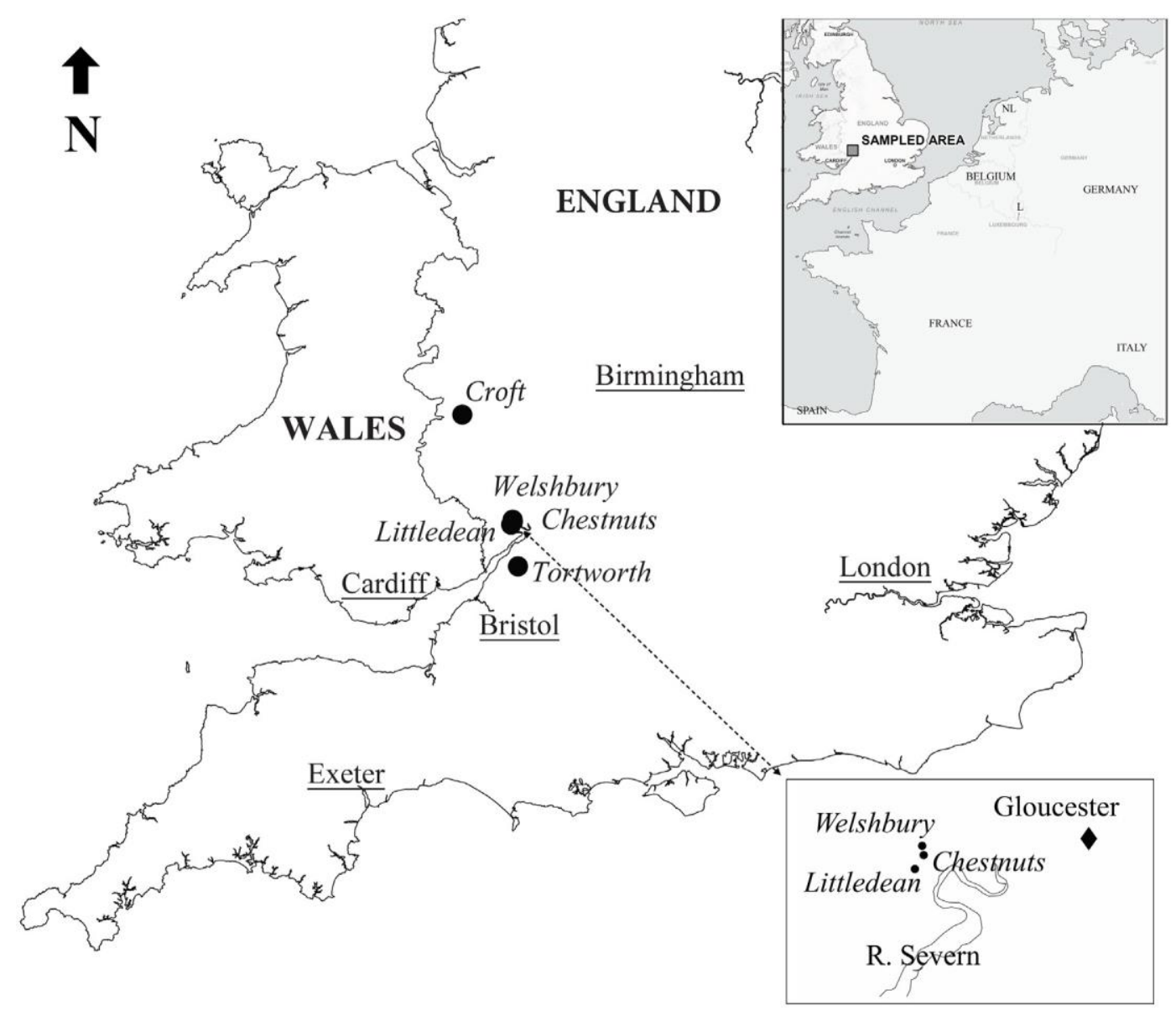

Figure 1. Map of the sampled sites in western England, in their European context.

notes: “ $\odot$ crown copyright and Database right [2016]. ordnance Survey (Digimap licence). contains public sector information licensed under the open Government licence v3.0." 


\section{Methods}

Stem cores and sawn radial sections were extracted from selected living and dead sweet chestnut trees. Analysis of growth rings was attempted, to define actual ages for those tree sections and to identify individual tree growth patterns for sweet chestnut. These sweet chestnut growth patterns were then compared with standard dendrochronological reference sequences for oak Quercus spp., to test for similarity of growth-ring sequences between sweet chestnut and oak.

\section{Site selection}

A range of study sites in Gloucestershire and Herefordshire was examined to find representative samples of ancient, mature standard and coppice-grown sweet chestnut trees. Five sites suitable for sampling were identified and permission to sample trees was received from the site owners:

(1) Croft Castle (parkland), Herefordshire (52.281722, -2.821361; NGR: SO 441652) - National Trust;

(2) Littledean Hall (historic avenue), Gloucestershire (51.815722, -2.476444; NGR: SO 673131) - James Dickens (private, no access);

(3) Chestnuts Wood (high forest), Gloucestershire (51.828222, -2.463972; NGR: SO 681145) - Forest Enterprise England (West England Forest District);

(4) Tortworth (parkland), Gloucestershire (51.795944, -2.548528: NGR: ST 704933) - Tortworth Estates (private, no access);

(5) Welshbury Camp (stored coppice), Gloucestershire (51.837833, -2.469333; NGR: SO 678156) - Forest Enterprise England (West England Forest District). 
A brief description of each site is given in the Results section. Figure 1 shows the locations of the sampled sites in western England, in their European context.

\section{Sampling and Preparation}

Trees were sampled by coring living wood using a $5 \mathrm{~mm}$ or $12 \mathrm{~mm}$ diameter Haglöf increment borer, or by cutting sections in dead wood. Core samples were taken at approximately 1 to $1.3 \mathrm{~m}$ from the root collar. Girth measurements were recorded at the point of sampling. Extracted cores were immediately glued to wooden laths onsite and stored to dry before analysis. Sawn sections were taken from felled deadwood and bough stub ends, as radial wedges or circular discs incorporating pith-to-bark ring series, avoiding rot, cavities and shake. The large-dimension segments were removed to the laboratory and cut to a narrow wedge, then planed to produce a flat crosssection perpendicular to the grain suitable for microscope stage analysis. The section strips were glued on to wooden laths and stored in a dry environment. All growth-ring sequences were revealed by sanding with progressively finer grits to a 400 grit, to enable measuring.

\section{Measuring and cross-matching}

Standard dendrochronological techniques were used for sample preparation, measurement, cross-matching and dating (Historic England, 1998). Growth-ring sequences were measured under a $\times 20$ stereomicroscope to an accuracy of $0.01 \mathrm{~mm}$ using a microcomputer-based travelling stage. Each core sample was measured twice, from the centremost (closest to pith) ring to the outermost ring (closest to bark). The measurements from each sample were visually plotted to identify cross-matches and eliminate errors. Where series visually matched satisfactorily at the appropriate offset they were averaged for use in subsequent analysis. Statistical cross-correlation 
algorithms were used to search for growth-ring sequence correlations. This search produces " $t$-values": $t$-values in excess of 3.5 were taken to be significant (Baillie 1982) and indicative of acceptable matching positions.

\section{Growth rate}

Tree growth-ring series contain age trends, reflecting the general reduction in ring widths as trees get progressively older, with formative, mature and senescent phases of growth (White, 1998). For visual comparison of tree growth rates, cumulative plots were produced to indicate growth trends (Figure 2). Trees are presumed to be in decline where consecutive decades have mean growth of $\leq 0.50 \mathrm{~mm} / \mathrm{yr}$ (White 1998): we used decadal growth rates of $\leq 2.00 \mathrm{~mm} / \mathrm{yr}$ to identify the onset of senescent growth for sweet chestnut.

\section{Determination of Germination Date}

The centre-of-tree (pith) date obtained by sampling at a height above the ground may not represent the absolute age of the tree (Telewski \& Lynch, 1991). We added 5 years to the measured age to account for the likely discrepancy between a pith date obtained at ground level and that obtained at 1.0 to $1.3 \mathrm{~m}$.

Where core samples did not include the central ring (pith), the number of missing rings to the pith was estimated using a transparent acetate sheet marked with concentric rings of uniform width to match the inner-most ring widths of the sample (Villalba \& Veblen, 1997).

Where interior portions of the tree were not recovered by the cored or sawn sections, owing to rotted-out pith/early heartwood, then the number of missing rings was calculated from the radius $(r=\operatorname{circ} / 2 \pi)$ divided by the mean ring width derived 
from the measured section, minus the total number of rings counted (measured and unmeasured) in the section.

Tree-ring analysis was achieved using a dendrochronological programme suite (Tyers, 1999).

\section{Results}

A summary of the results of the analysis across all five sites is shown in Table 1.

Cumulative ring widths (Figure 2) and decadal growth rates (Figure 3) were plotted to describe the underlying biological age growth trend. Regression analysis of the relationship of age to girth was undertaken and is represented in Figure 4.

[t]Table 1 near here[/t].

\section{Individual site results}

Site 1. Croft Castle, nr Leominster, Herefordshire

A veteran sweet chestnut tree that had been felled in 1981 (when still alive) and left dead intact on the ground was sampled by cutting three sections with a chainsaw with a 4-foot 
Table 1. Summary of dendrochronological analysis of seven cores and five sawn sections from eight sweet chestnut trees in western England.

\begin{tabular}{|c|c|c|c|c|c|c|c|}
\hline $\begin{array}{l}\text { Tree series code } \\
\text { name }\end{array}$ & $\begin{array}{l}\text { Cross-matched } \\
\text { sequence date } \\
\text { range/not } \\
\text { synchronised }\end{array}$ & $\begin{array}{c}\text { Measured } \\
\text { rings + } \\
\text { (unmeasured } \\
\text { rings) + years } \\
\text { to known } \\
\text { last growth } \\
\text { season }\end{array}$ & $\begin{array}{l}\text { Number } \\
\text { of missing } \\
\text { rings to pith } \\
\text { (calculated } \\
\text { /estimated) }\end{array}$ & $\begin{array}{c}\text { Mean ring } \\
\text { width (mm) }\end{array}$ & $\begin{array}{l}\text { Tree girth } \\
(\mathrm{m}) \text { at } 1.3 \mathrm{~m}\end{array}$ & $\begin{array}{l}\text { Age circa } \\
\text { years }\end{array}$ & $\begin{array}{c}\text { Start date } \\
\text { circa AD }\end{array}$ \\
\hline HACCO1A & AD 1779-1975 & $(29)+197+5$ & & 4.27 & 9.00 & & \\
\hline HRCCO1B & AD 1759-1977 & $(12)+219+3$ & & 4.98 & 9.00 & & \\
\hline Mean 01A/01B & & 233 & Hollow $<76$ & 4.63 & 9.00 & 312 & 1668 \\
\hline HRCCOIC & AD 1716-1970 & $255+10$ & 3 & 2.31 & 5.55 & & \\
\hline $\begin{array}{l}\text { Single tree mean } \\
\text { HACCO1 }\end{array}$ & AD 1716-1977 & 262 & & 3.85 & 9 & 312 & 1668 \\
\hline GLLH01 & AD 1865-1998 & $134(+17)$ & $<148$ & 3.07 & 5.95 & 304 & 1710 \\
\hline GLLH02 & AD 1942-2010 & $(42)+69+5$ & $<142$ & 4.95 & 7.99 & 263 & 1751 \\
\hline $\begin{array}{l}\text { Site mean } \\
\text { LDEAN-2 }\end{array}$ & AD $1865-2010$ & $146+5$ & & 3.57 & & 304 & 1710 \\
\hline GLLH03 & Not sync. & $111+(50)$ & 56 & 3.58 & 4.79 & 222 & 1792 \\
\hline GLCW01 & AD 1901-2011 & $111(+8)+1$ & 6 & 3.08 & 2.75 & 131 & 1880 \\
\hline GLWC01 & Not sync. & 63 & 5 & 3.59 & 1.70 & 75 & 1940 \\
\hline GLTO01 & Not sync. & 95 & $<99$ & 2.99 & 3.64 & 194 & 1820 \\
\hline GLTO06 & Not sync. & $59(+56)$ & $<211$ & 3.59 & 6.1 & 270 & 1739 \\
\hline Site mean TORT-2 & Not sync. & 95 & & & & & \\
\hline GLTO04 & Not sync. & 63 & 0 & 1.03 & .42 & 63 & $\mathrm{n} / \mathrm{a}$ \\
\hline GLTO05 & Not sync. & 122 & 0 & .76 & .7 & 122 & $\mathrm{n} / \mathrm{a}$ \\
\hline
\end{tabular}

Note: The italic values are indicates estimated values.

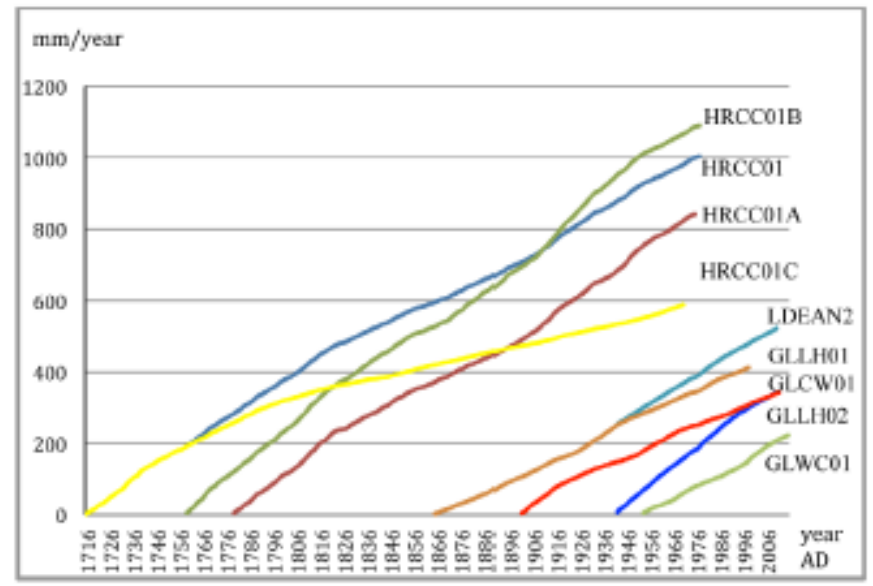

Figure 2. Cumulative growth-ring widths plotted for the five cross-matched sweet chestnut trees.

bar, as shown in Figures 5, 6, and 7. For each section, the tree girth was measured and its position on the tree was recorded (as post-felling and pre-felling). The sampled tree was labelled HRCC01 and the three sections numbered 01A, 01B and 01C. 


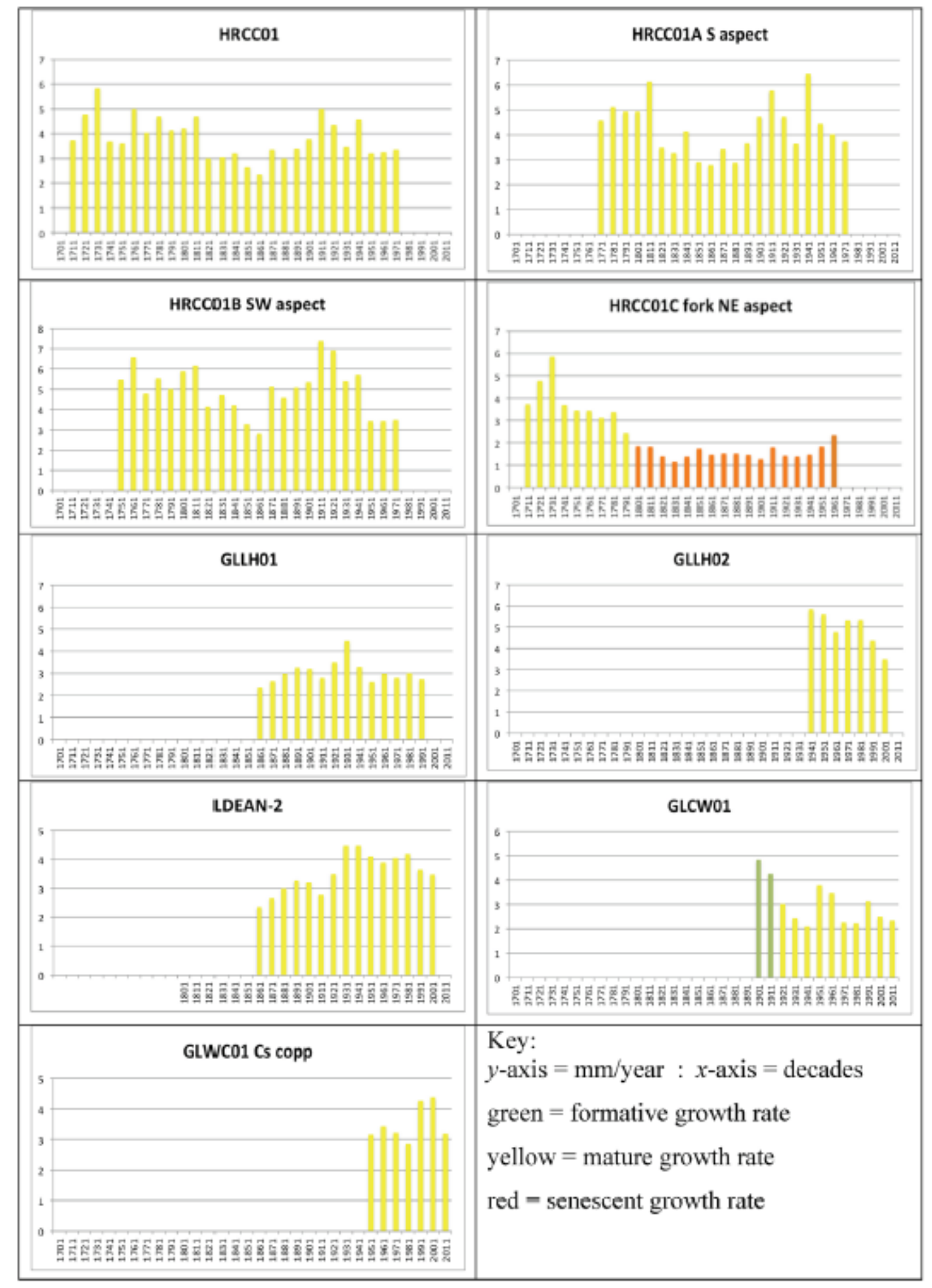

Figure 3. Decadal growth rates for each measured sequence and the two combined series from the five 
Measuring \& cross-matching

Three radial wedge sections were recovered from this 9-metre girth tree: HRCC01A and HRCC01B were sawn from the base of the trunk, working from the original felling cut; and HRCC01C was sawn from a major fork at 3.8 metres up-trunk.

Measured ring sequences from the three sections were found to cross-match together

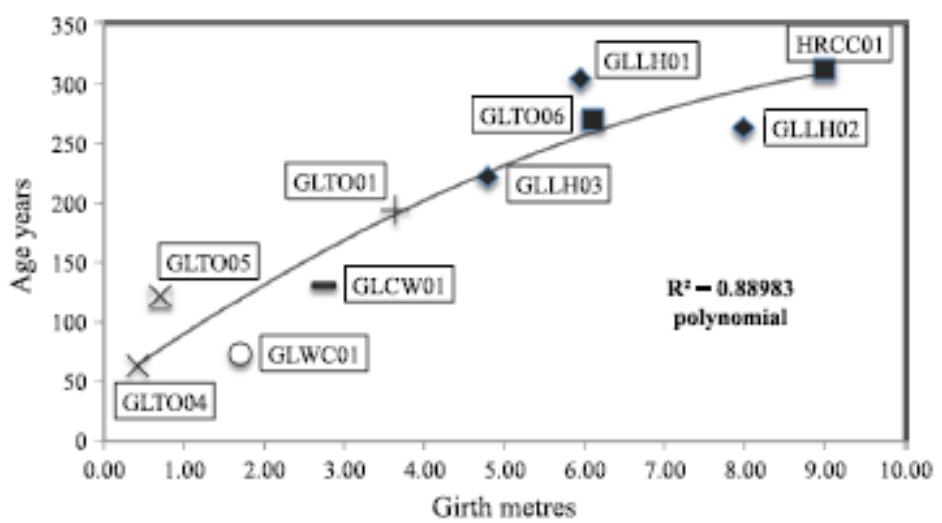

Figure 4. Regression analysis of girth against age for the five sweet chestnut trees.

Notes: In Figure 4 the measured girths at each tree section have been plotted against the measured/estimated age of each section. The type of tree for each section has been noted, so that residual values might be interpreted: $\times$ branch stub, O coppice regrowth stem, $\square$ veteran parkland tree, $\bullet$ ancient avenue tree, - woodland standard tree, + regeneration from collapsed ancient tree.

with $t$-values $>8$ (Table 2) and were combined to form a continuous 235-year series, labelled HRCC01.

Table 2 Cross-matching $t$-values between growth ring series from three radial sections sawn from the dead Croft Castle sweet chestnut tree HRCC 01.

\begin{tabular}{lcccc}
\hline Tree section & HRCC01B & HRCC01C & Start date & End date \\
\hline HRCC01A & 11.40 & 9.12 & AD1779 & AD1975 \\
HRCC01B & & 8.06 & AD1759 & AD1977 \\
HRCC01C & & & AD1716 & AD1970 \\
\hline
\end{tabular}

The single tree mean series HRCC01 spans from AD 1716 to AD 1977. The earlier start date for the section HRCC01C from higher up the tree is explained by the loss of wood from the decayed hollow core at the base of the tree (see Figures 5 and 6): the upper section provided forty-three annual rings that were missing between its measured pith date and the earliest measurable ring in the lower sections. The end 
dates are all slightly dissimilar owing to perimeter decay during the 34 years that this tree had been lying dead. The annual resolution of the HRCC01 series has been confirmed by cross-matching against a wide number of oak reference chronologies (Table 3).

Age determination

Table 1 provides the raw data from which the ages of the three sections have been calculated. Using measured and unmeasured rings and an estimate of missing rings (derived from the calculation explained in Methods), the Croft tree has been dated as originating from circa AD 1668.

Growth rate characteristics

Figure 3 illustrates the decadal growth rates for the three Croft sections. The two main trunk sections $01 \mathrm{~A}$ and $01 \mathrm{~B}$ display consistent decadal average growth rates of $>2.8$ $\mathrm{mm} / \mathrm{yr}$ in two evident phases of faster then slower growth, but without any major transformation between formative, mature or senescent growth phases. Given the age of this tree and that it was dying when felled, the absence of a clear senescent growth phase seems surprising. The formative growth phase has probably been lost in the rotted-out pith and early heartwood - up to 90 years of early growth are missing from various segments of the hollow trunk (see Figures 5 and 6). 


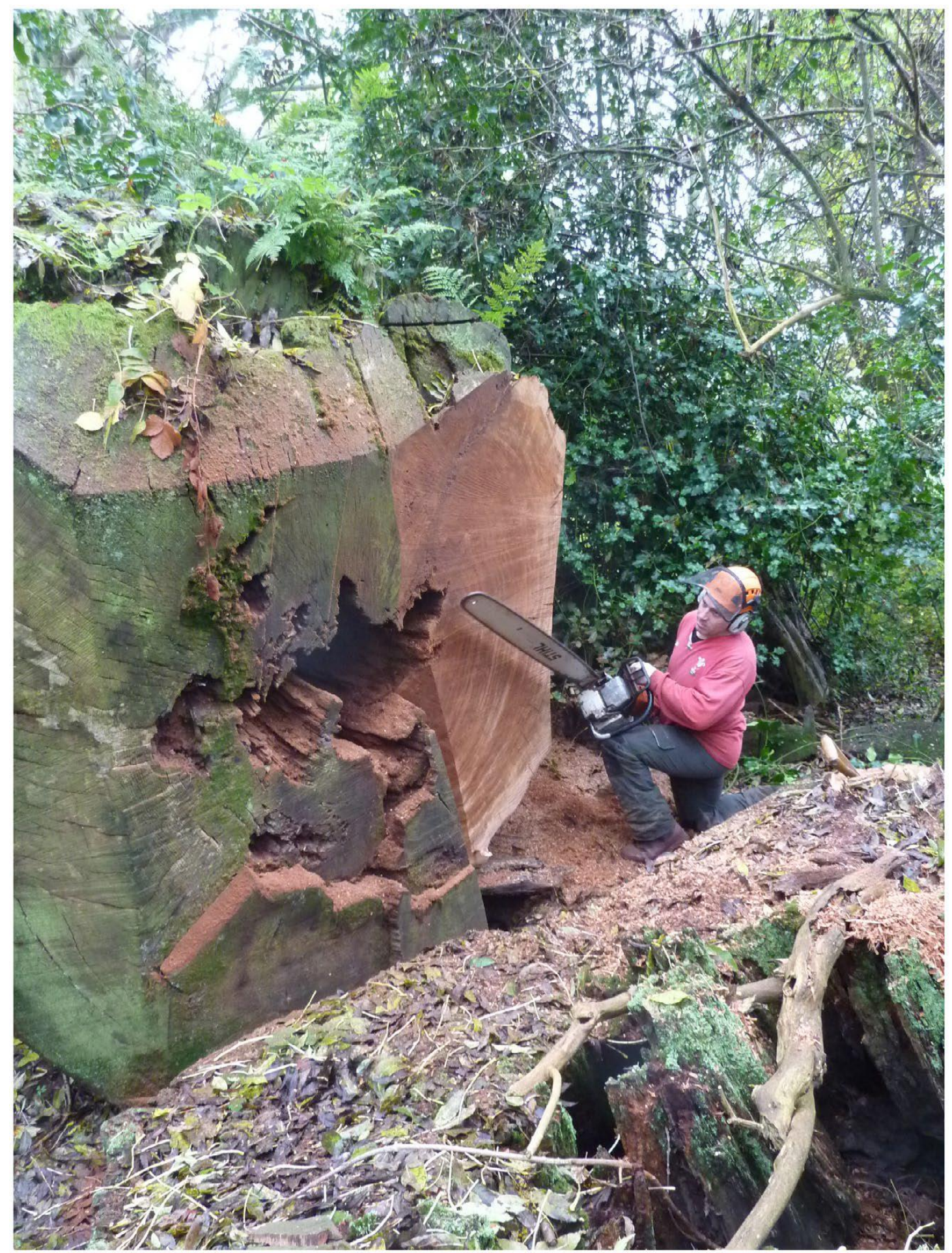

Figure 5. Croft Castle chestnut tree - location of sawn sections HRCC 01 and HRCC 02. Image (C) Rob Jarman.

The fork-trunk section 01C (Figure 7) had a much slower growth rate than the main trunk, showing a marked shift from mature to senescent growth $(<2 \mathrm{~mm} / \mathrm{yr}$ decadal average) at c. AD 1800 (when the tree was 120 years old). This might have 
been caused by loss of part of this fork in the upper canopy, or by competition from the adjacent fork of this tree. Lying on the ground on the opposite side of the felled tree is a massive fallen bough that may have been the dominant section of the upper canopy.

\section{Site 2. Littledean Hall, Littledean, Gloucestershire}

Three core samples were taken from three sweet chestnut trees in the historic avenue in front of the Hall (see Figure 8).

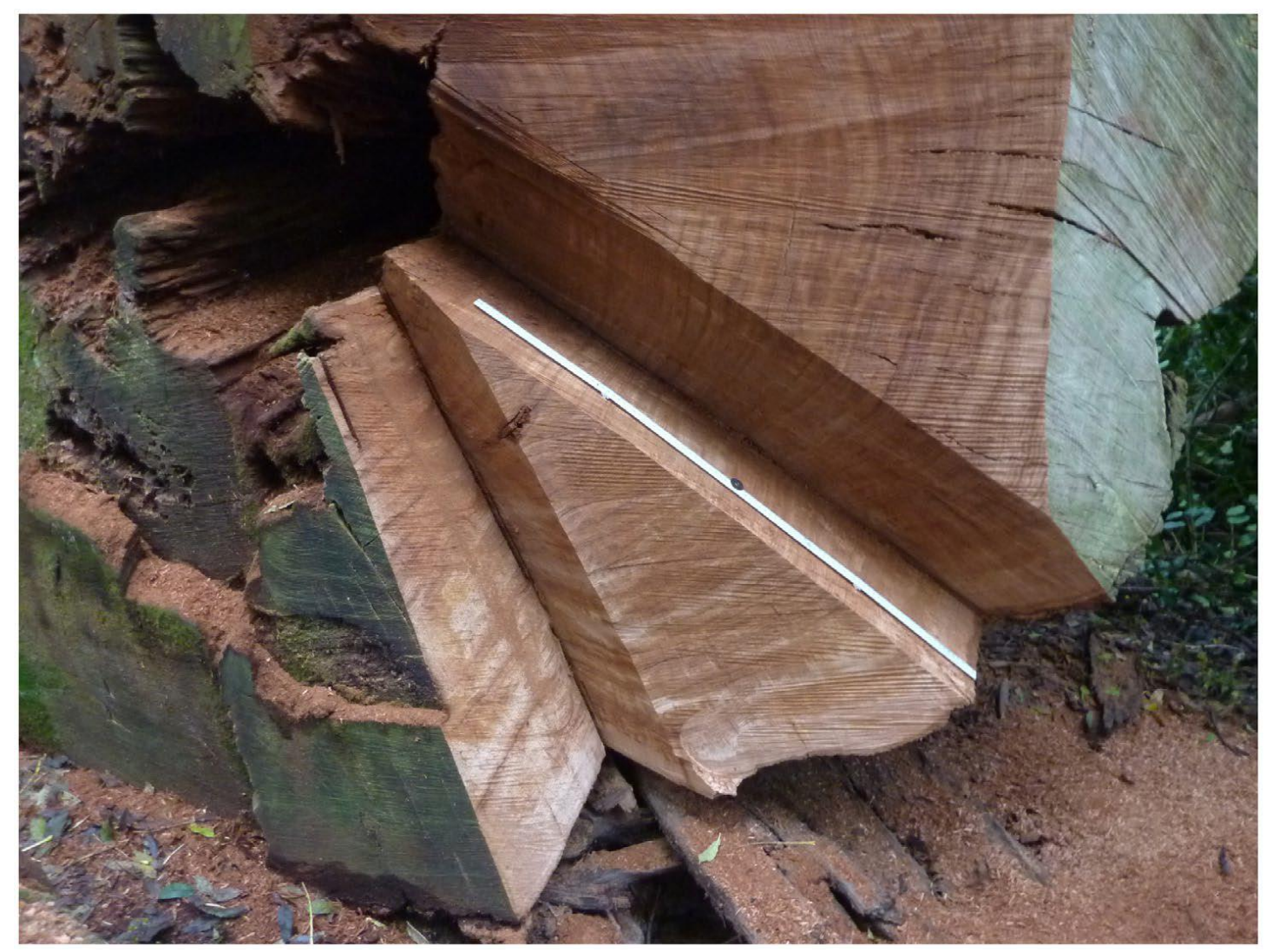

Figure 6. Croft - sawn sections HRCC 01 and HRCC 02. Image (C) Rob Jarman. 
Table 3. Cross-matching of HRCC 01 against oak reference chronologies from England and Brittany (France).

\begin{tabular}{|c|c|c|c|c|c|}
\hline \multicolumn{6}{|c|}{ HRCC01 dated AD 1716 to AD 1977} \\
\hline File & Start date & End date & $t$-value & Overlap (yr.) & Reference chronology \\
\hline ENGLAND & AD 404 & AD 1981 & 8.03 & 262 & $\begin{array}{l}\text { England Master Chronology (Baillie \& Pilcher, } \\
\text { 1982) }\end{array}$ \\
\hline WINCHSTR & AD 1635 & AD 1972 & 7.84 & 257 & Winchester, Hampshire (Barefoot, 1975) \\
\hline Stone-1 & AD 1387 & AD 1998 & 7.32 & 262 & $\begin{array}{l}\text { Stoneleigh Abbey, Warwickshire (Howard, } \\
\text { Laxton, \& Litton, 2000) }\end{array}$ \\
\hline East_mid & AD 882 & AD 1981 & 7.19 & 262 & East Midlands (Laxton \& Litton, 1988) \\
\hline Oxford & AD 1781 & AD 1978 & 6.72 & 197 & Oxford Oak, Oxfordshire (Pilcher \& Baillie, 1980) \\
\hline SOTTERLY & AD 1586 & AD 1981 & 6.53 & 262 & $\begin{array}{l}\text { Sotterley park, Suffolk (Briffa, Wigley, Jones, } \\
\text { Pilcher, \& Hughes, 1986) }\end{array}$ \\
\hline HerWor2 & AD 1729 & AD 1969 & 6.36 & 241 & $\begin{array}{l}\text { Hereford and Worcester (Siebenlist-Kerner, } \\
\text { 1978) }\end{array}$ \\
\hline VICTORY & AD 1640 & AD 1800 & 6.09 & 262 & HMS Victory (Barefoot, 1975) \\
\hline BritanyA & AD 1609 & AD 1985 & 5.82 & 262 & Brittany A - France (Guibal, 1987) \\
\hline MSC & AD 1820 & AD 1995 & 5.82 & 158 & $\begin{array}{l}\text { Mendhams Corner, Sotterley Estate, Suffolk } \\
\text { (Moir, 1996) }\end{array}$ \\
\hline ALDSW-LP & AD 1672 & AD 2012 & 5.69 & 262 & $\begin{array}{l}\text { Lodge Park, Aldsworth, Gloucestershire (Moir, } \\
\text { 2012d) }\end{array}$ \\
\hline Langley & AD 1856 & AD 2011 & 5.22 & 122 & Langley Park, Buckinghamshire (Agin, 2011) \\
\hline
\end{tabular}

Measuring \& cross-matching

Three measured series coded GLLH01, GLLH02 and GLLH03 were established. Two series GLLH01 and GLLH02 cross-matched together, with a $t$-value of 7.6, and were combined to form a 146-year site mean chronology coded LDEAN-2. 


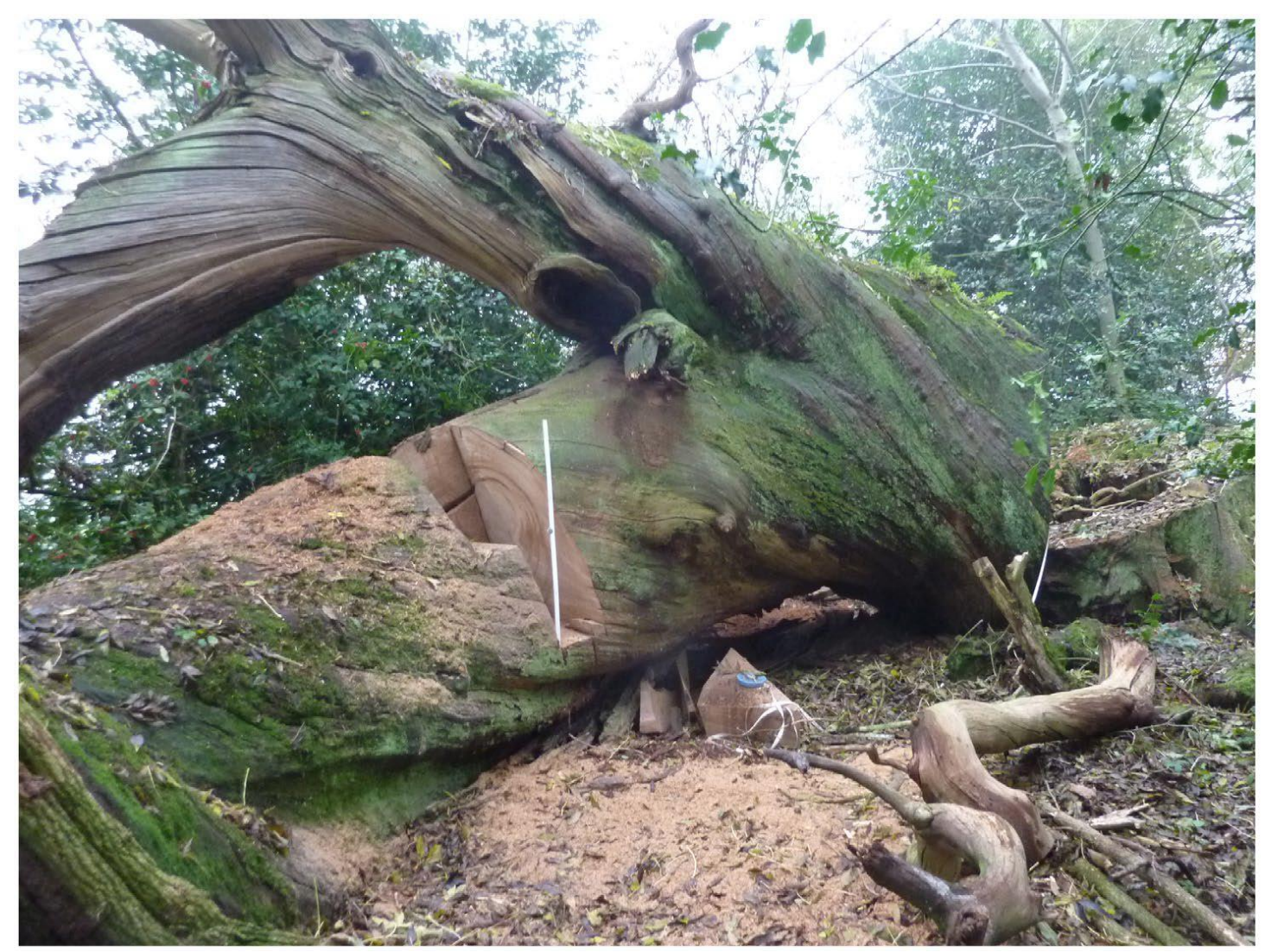

Figure 7. Croft - sawn section HRCC 03. Image (C Rob Jarman.

The growth rings of GLLH03 were unmeasurable for intra-ring growth parameters and could only be counted, producing an age calculation (Table 1). The site mean LDEAN-2 was found to match closely with the Croft series $(t=6.18)$; it also produced consistently high $t$-values against oak reference chronologies (Table 4), with the first ring of the series at AD 1865 and the final ring of the series at AD 2010.

\section{Age determination}

Tree ages were calculated for the three trees using the actual and estimated ring counts (Table 1). Tree GLLH01 is the oldest, although not with the largest girth, whereas tree GLLH02 has the largest girth and so appears older, swollen by the protuberances characteristic of mature sweet chestnut trees. Tree GLLH03 is dying and shedding bark: the outer $10 \mathrm{~cm}$ section of the core was unmeasurable owing to degraded wood. The growth rings were unmeasurable for intra-ring growth 
parameters, so no assessment of decadal growth patterns was made. The tree age estimate is younger than the other trees surveyed and it is one of the smallest (not necessarily youngest) trees in this avenue of eight veteran trees.

Growth rate characteristics

These three trees displayed only a mature growth rate. However, the relatively slow growth rate of GLLH01 may result from its position on a bank that constrains the tree's root system (Figure 8). GLLH02 shows the steepest growth curve, although the measured section of the core was short, perhaps unrepresentative of the growth rate of the tree in earlier decades.

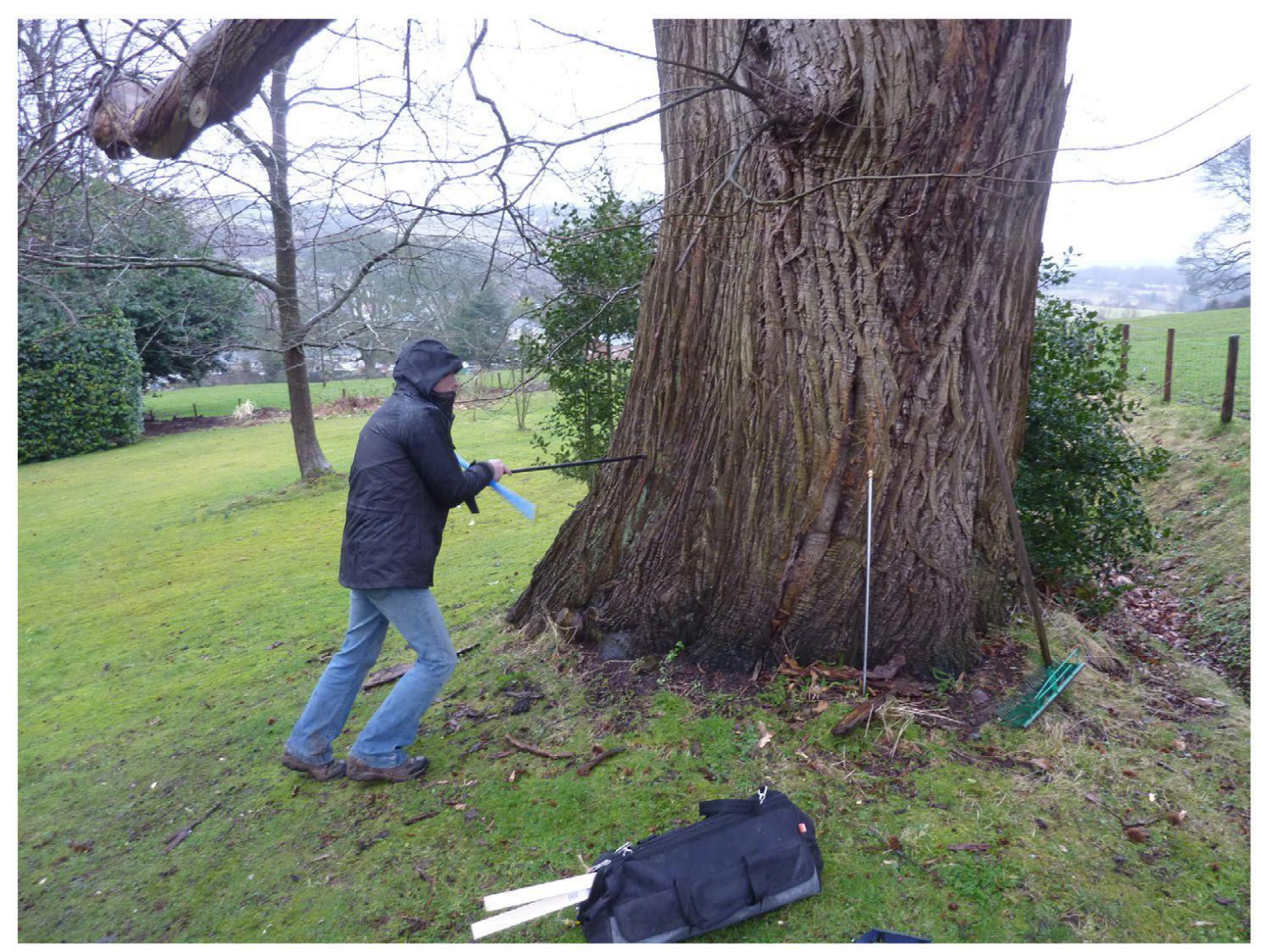

Figure 8. Littledean Hall - coring tree GLLH01. Image @ Rob Jarman. 
Table 4. Cross-matching of LDEAN-2 against the HRCC 01 chestnut chronology and oak reference chronologies from England and Brittany (France).

\begin{tabular}{|c|c|c|c|c|c|}
\hline \multicolumn{6}{|c|}{ LDEAN-2 dated AD 1865 to AD 2010} \\
\hline File & Start date & End date & $t$-value & Overlap (yr.) & Reference chronology \\
\hline HRCC01 & AD 1716 & AD 1977 & 6.18 & 113 & $\begin{array}{l}\text { Chestnut - Croft Castle, Herefordshire (this } \\
\text { report) }\end{array}$ \\
\hline SOMERST40 & AD 1095 & AD 2011 & 5.27 & 146 & Somerset county chronology (Moir, 1996) \\
\hline ENGLAND & AD 404 & AD 1981 & 5.02 & 146 & $\begin{array}{l}\text { England Master Chronology (Baillie \& Pilcher, } \\
\text { 1982) }\end{array}$ \\
\hline Langley & AD 1856 & AD 2011 & 4.97 & 146 & Langley Park, Buckinghamshire (Agin, 2011) \\
\hline COBHAM & AD 1770 & AD 2001 & 4.77 & 137 & $\begin{array}{l}\text { Modern trees - Cobham, Kent (Arnold, } \\
\text { Howard, Laxton, \& Litton, 2003) }\end{array}$ \\
\hline SLG & AD 1764 & AD 1993 & 4.76 & 129 & $\begin{array}{l}\text { Scarles Grove, Sotterley Estate, Suffolk (Moir, } \\
\text { 1996) }\end{array}$ \\
\hline East_mid & AD 882 & AD 1981 & 4.73 & 117 & East Midlands (Laxton \& Litton, 1988) \\
\hline TILLȲOAK & AD 1833 & AD 2015 & 4.60 & 146 & $\begin{array}{l}\text { Oak - Tilley Village, Wem, Shropshire (Moir, } \\
\text { 1996) }\end{array}$ \\
\hline BSWR01 & AD 1807 & AD 2011 & 4.56 & 146 & $\begin{array}{l}\text { Modern Oak - Yeo Mead, Congresbury, } \\
\text { Somerset (Moir, 2012a) }\end{array}$ \\
\hline EYNSF-LL & AD 1737 & AD 2011 & 4.54 & 146 & $\begin{array}{l}\text { Lullingstone Country Park, Eynsford, Kent } \\
\text { (Moir, 2012c) }\end{array}$ \\
\hline ALDSW-LP & AD 1672 & AD 2012 & 4.47 & 146 & $\begin{array}{l}\text { Lodge Park, Aldsworth, Gloucestershire (Moir, } \\
\text { 2012d) }\end{array}$ \\
\hline BritanyA & AD 1609 & AD 1985 & 4.44 & 121 & Brittany A - France (Guibal, 1987) \\
\hline
\end{tabular}

\section{Site 3. Chestnuts Wood, Littledean}

One core sample was taken from a windthrown (in AD 2012) sweet chestnut tree, and labelled GLCW01 (Figure 9).

Measuring \& cross-matching

The measured series from tree GLCW01 produced consistently high $t$-values against a range of oak reference chronologies (Table 5), with the first ring of the series at AD 1901 and the final ring at AD 2011. It did not cross-match with the two chestnut series from Croft and Littledean Hall.

Age determination

This tree proved to be 131 years old from measured, unmeasured and estimated ring counts, so was established in circa AD 1880, possibly by regeneration from previous coppice. 
Growth rate characteristics

This is the only tree sampled in this survey to indicate a formative growth phase. The early 'fast' growth rate of $4.54 \mathrm{~mm} / \mathrm{yr}$ is not fast for sweet chestnut and the subsequent 'mature' rate of $2.72 \mathrm{~mm} / \mathrm{yr}$ is slow, but a shift in decadal growth rates for this tree is evident (Figure 3). The age at transition - thirty-nine years - may seem late for a shift from a formative to a mature growth rate.

\section{Site 4. Tortworth, Gloucestershire}

Two sweet chestnut trees were sampled here - from outlying boughs of the iconic ancient Tortworth Chestnut; and from a neighbouring veteran tree 25 metres to the west.

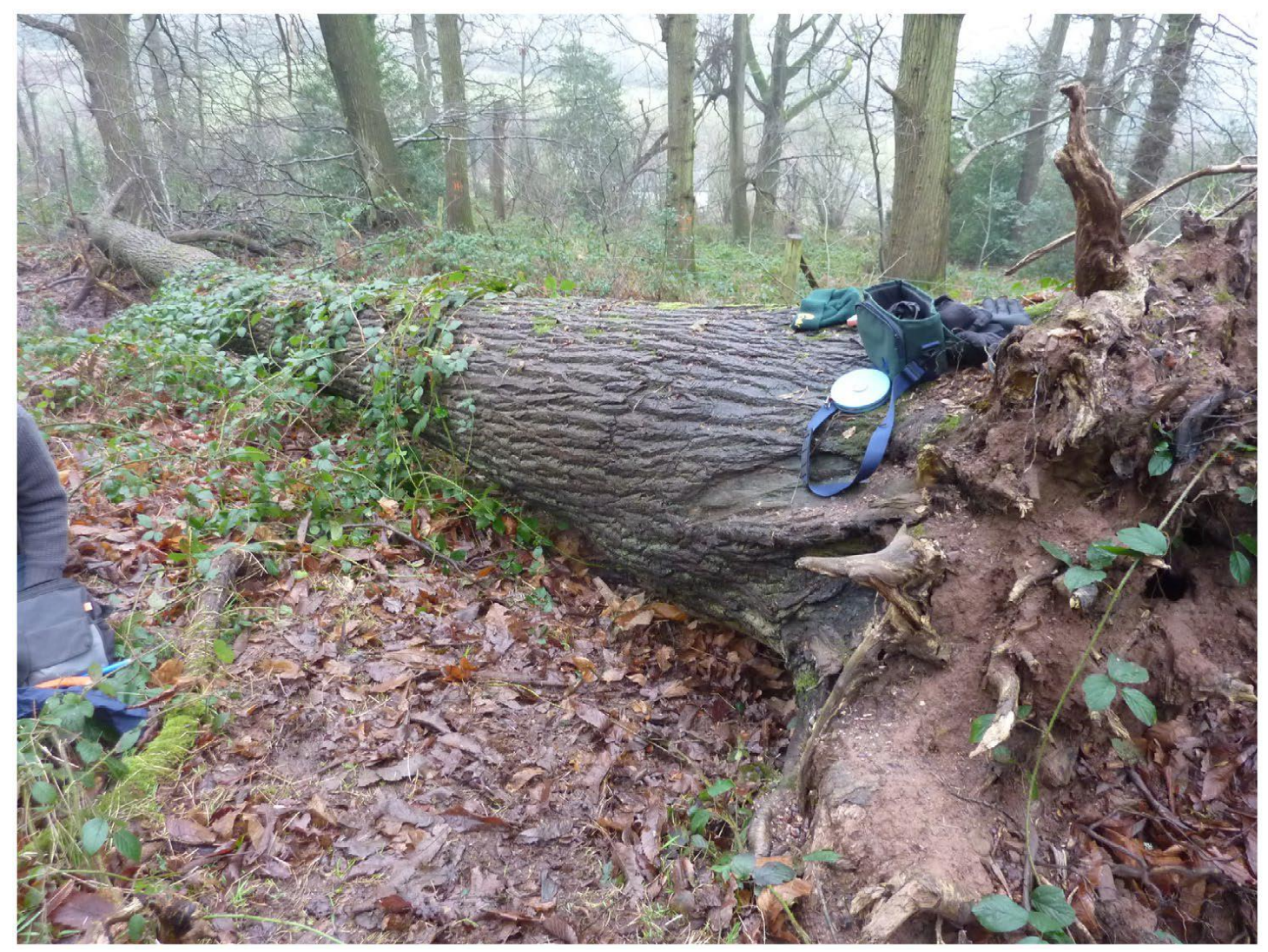

Figure 9. Chestnuts Wood - coring tree GLC W01. Image (C) Rob Jarman. 
Table 5. Cross-matching of GLC W01 against oak reference chronologies from England.

\begin{tabular}{|c|c|c|c|c|c|}
\hline \multicolumn{6}{|c|}{ GLCW01 dated AD 1901 to AD 2011} \\
\hline File & Start date & End date & $t$-value & Overlap (yr.) & Reference chronology \\
\hline East_mid & AD 882 & AD 1981 & 5.75 & 81 & East Midlands (Laxton \& Litton, 1988) \\
\hline ENGLAND & AD 404 & AD 1981 & 5.22 & 81 & $\begin{array}{l}\text { England Master Chronology (Baillie \& Pilcher, } \\
\text { 1982) }\end{array}$ \\
\hline Savenake & AD 1651 & AD 2006 & 4.43 & 106 & Savernake Forest, Wiltshire (Moir, 1996) \\
\hline MDEAN-OR & AD 1779 & AD 2013 & 4.31 & 111 & $\begin{array}{l}\text { Horsepool Bottom Nature Reserve, } \\
\text { Mitcheldean, Gloucestershire (Moir, 2014) }\end{array}$ \\
\hline Stone-1 & AD 1387 & AD 1998 & 4.24 & 98 & $\begin{array}{l}\text { Stoneleigh Abbey, Warwickshire (Howard et al., } \\
\text { 2000) }\end{array}$ \\
\hline HNTLY-TF & AD 1829 & AD 2007 & 4.10 & 107 & $\begin{array}{l}\text { Tuns Farm House, Huntley, Gloucestershire } \\
\text { (Moir, 2012b) }\end{array}$ \\
\hline EYNSF-LL & AD 1737 & AD 2011 & 3.82 & 111 & $\begin{array}{l}\text { Lullingstone County Park, Eynsford, Kent (Moir, } \\
\text { 2012c) }\end{array}$ \\
\hline FRW017 & AD 1952 & AD 2002 & 3.72 & 102 & $\begin{array}{l}\text { Oak tree - Frosebury, Worplesdon, Surrey } \\
\text { (Moir, unpublished) }\end{array}$ \\
\hline ALDSW-LP & AD 1672 & AD 2012 & 3.72 & 111 & $\begin{array}{l}\text { Lodge Park, Aldsworth, Gloucestershire (Moir, } \\
\text { 2012d) }\end{array}$ \\
\hline MSC & AD 1820 & AD 1995 & 3.61 & 95 & $\begin{array}{l}\text { Mendhams Corner, Sotterley Estate, Suffolk } \\
\text { (Moir, 1996) }\end{array}$ \\
\hline
\end{tabular}

Three core samples were taken from three boughs that had collapsed from the

Tortworth Chestnut historically, but had remained attached and had layered and regenerated; and two disc sections were cut from dead stub ends of two layered branches. One core was taken from the trunk of the neighbouring tree. The samples were given a site code GLTO and sequentially numbered 01-06 (see Figures 10, 11, and 12 and note the structural character of the ancient tree and its historically collapsed limbs).

Measuring \& cross-matching

Core samples GLTO02 and GLTO03 were impossible to ring count or measure owing to convoluted rings, perhaps from the growth stresses within these branches postcollapse, and were discarded from further analysis.

Four measured series GLTO01, GLTO04, GLTO05 and GLTO06 were established. Two of these - GLTO01 and GLTO06 - were cross-matched $(t=4.3)$ and combined into a 95-year site mean chronology coded TORT-2. This chronology did not produce high $t$-values against oak reference chronologies and failed to match 
the other sweet chestnut chronologies from this study: it remains undated by crossmatching.

Ring counts were taken from the 2 cores and the 2 disc sections (Table 1) to analyse the history of these trees.

Age determination

The Tortworth Chestnut tree is reputed to date from between AD 800-1150, but no archival evidence has been found to support this. It is unfortunate that only one of the three cores from the main tree components could provide a viable growth ring series. The GLTO01 core provided a pith date of c. AD 1820 for this upright trunk that had originated from a collapsed bough of the main tree. It is conjectured that this trunk started as a sprout when the bough collapsed (but remained attached, so continued to grow and then root as a layered bough).

The two branch stub end discs yielded measurable entire pith-to-bark sections, with very close-grown rings: GLTO04 has a diameter of $135 \mathrm{~mm}$ and 63 rings; GLTO05 has a diameter of $224 \mathrm{~mm}$ and 122 rings. 


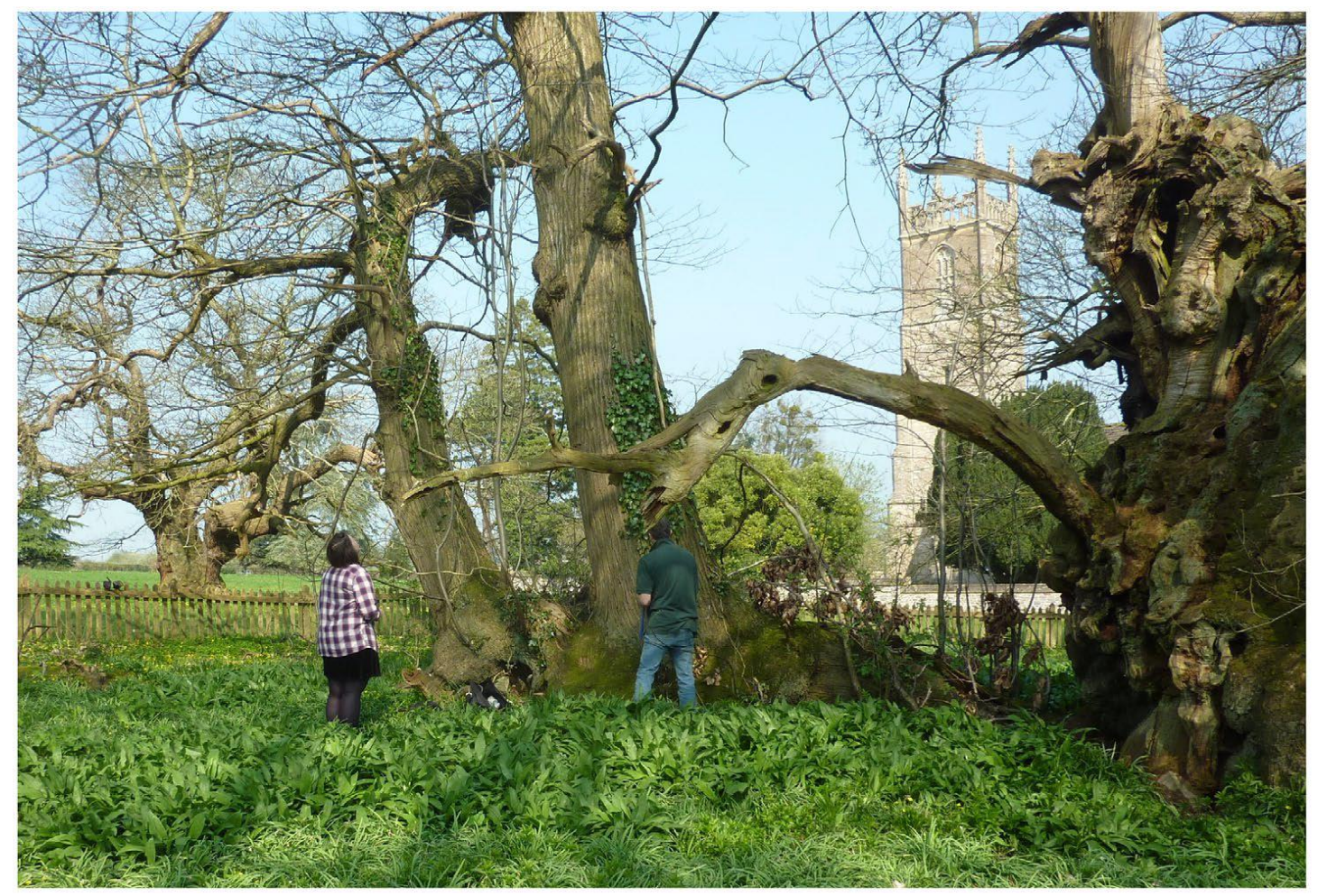

Figure10. Tortworth - coring tree GLTO 01. Image (C) Rob Jarman.

GLTO06 (the neighbouring tree) has been dated from the measured and unmeasured rings and girth ratio as $\sim 270$ years age, giving an establishment date of $\mathrm{c}$. AD 1739. This concurs with the known history of the former Tortworth Court gardens here.

Growth rate characteristics

The GLTO04 and GLTO05 discs from branch ends provide an insight into how slowly sweet chestnut wood can grow: GLTO05 had decadal growth means of 0.57 to $0.97 \mathrm{~mm} / \mathrm{yr}$ over its entire 122 years of growth. This fallen bough stub end was measured as $15.7 \mathrm{~m}$ from the main tree and it is possible that this bough had continued growing horizontally after collapsing, whilst it also sprouted new vertical stems (like GLTO01 and GLTO03). Alternatively, this bough end may originally have been in the upright canopy before the bough collapsed and was growing at this slow rate even in the canopy: on collapse, it may have continued at that slow growth 
rate until dying - the bough had evidently been dead for many years when surveyed in 2015. It would be especially informative for the historical analysis of this tree to find a reference chronology with which it can be cross-matched and dated.

Site 5. Welshbury Camp, Flaxley, Gloucestershire

One core sample was taken from a sweet chestnut tree (grown from an original coppice stool and singled at some time possibly pre-1985) and coded GLWC01 (Figure 13).

Measuring \& cross-matching

The series established from this sweet chestnut tree (GLWC01) was measured, giving sixty-three rings from near-pith to bark. However, cross-matching could not be established with any oak reference chronologies, nor with the three chestnut chronologies from this study, so this series remains undated. 


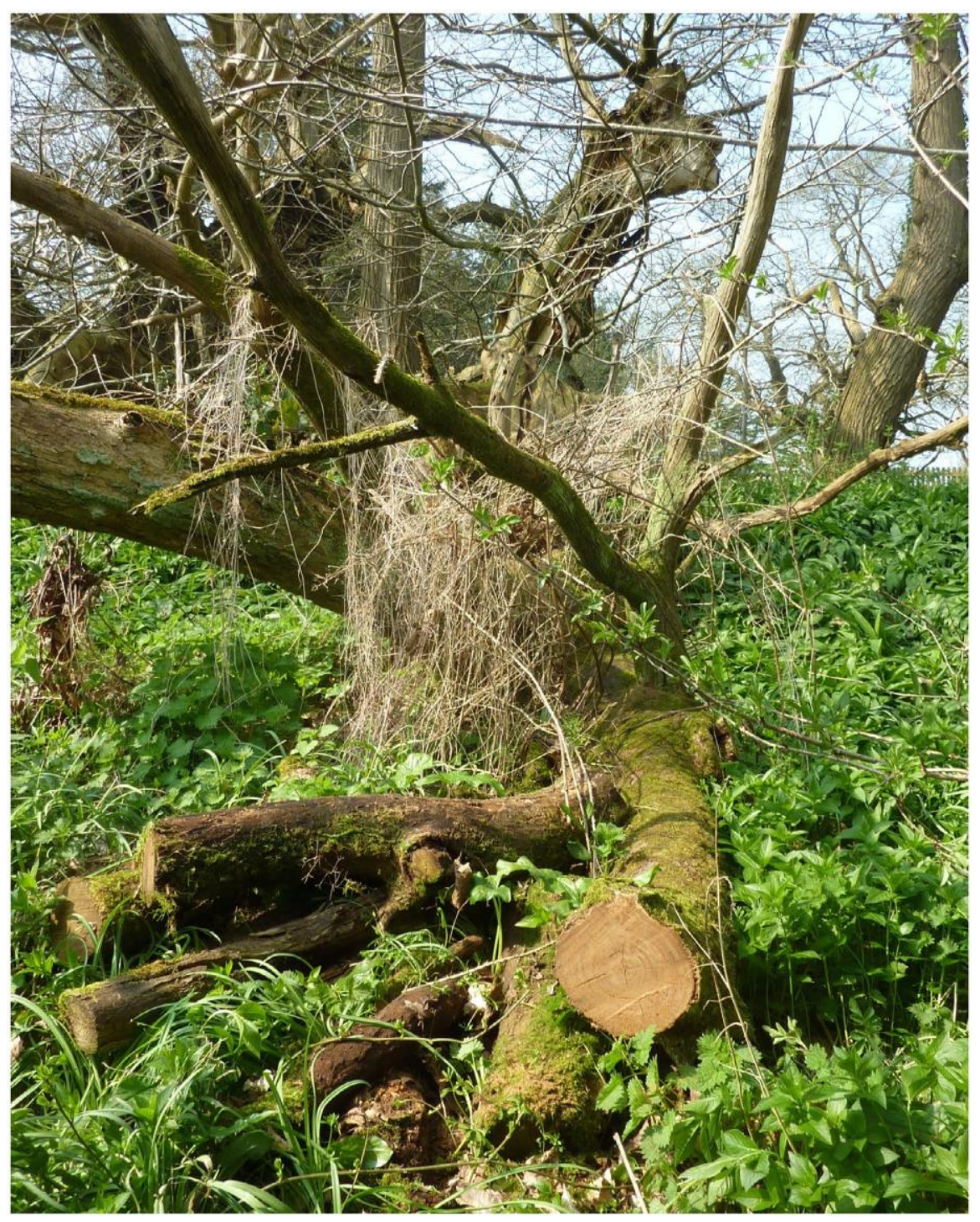

Figure 11. Tortworth - sawn section from stub end GLTO 05. Image @ Rob Jarman.

Age determination

The core allowed a full ring count from near-pith to bark. The outermost sapwood ring was recovered with bark, the stem was still alive and growing, and the missing rings to pith could be calculated from the ring curvature estimate as 5 years. The overall date of the series could be confirmed without cross-matching as 75 years (AD 1940-2015). 
Growth rate characteristics

The core missed the first five years of growth from the pith, so only mature growth rates appear in the section (Figure 3). This chestnut tree grew from a coppiced stool in a wood dominated by small-leaved lime Tilia cordata and its growth patterns may be uncharacteristic of sweet chestnut trees in other habitats. Figure 4 indicates

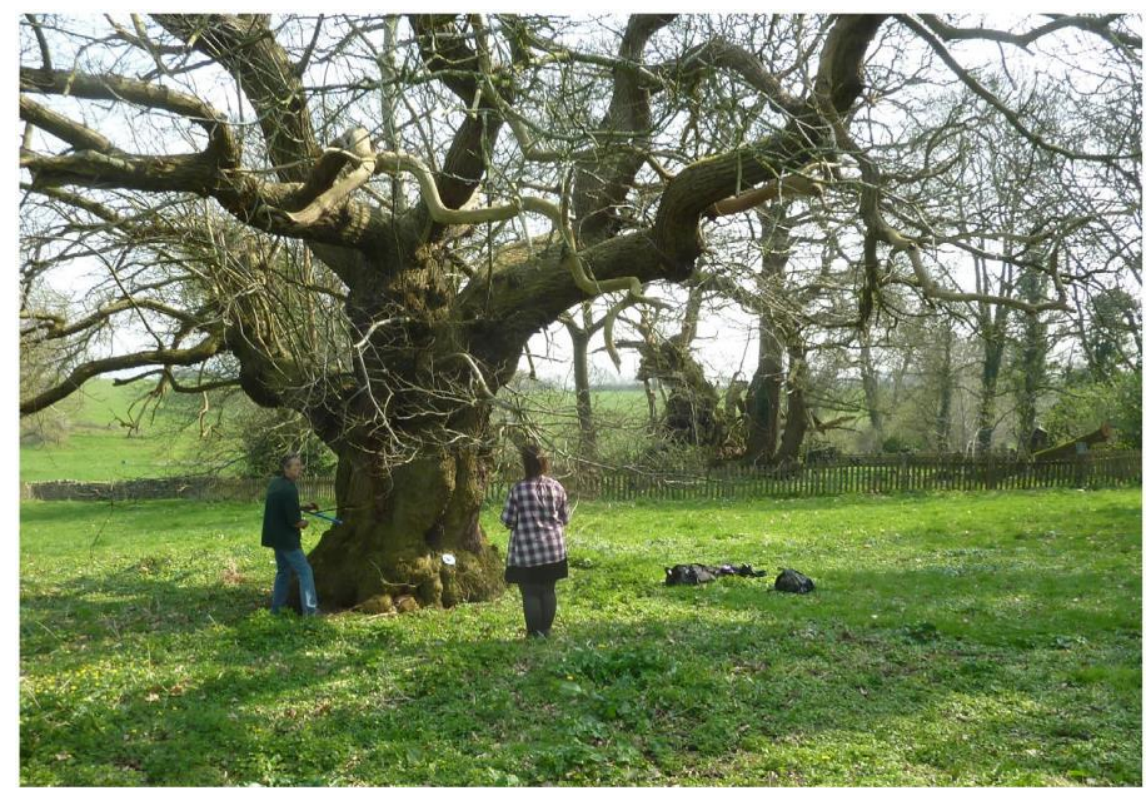

Figure 12. Tortworth - coring tree GLTO 06. Image (C Rob Jarman.

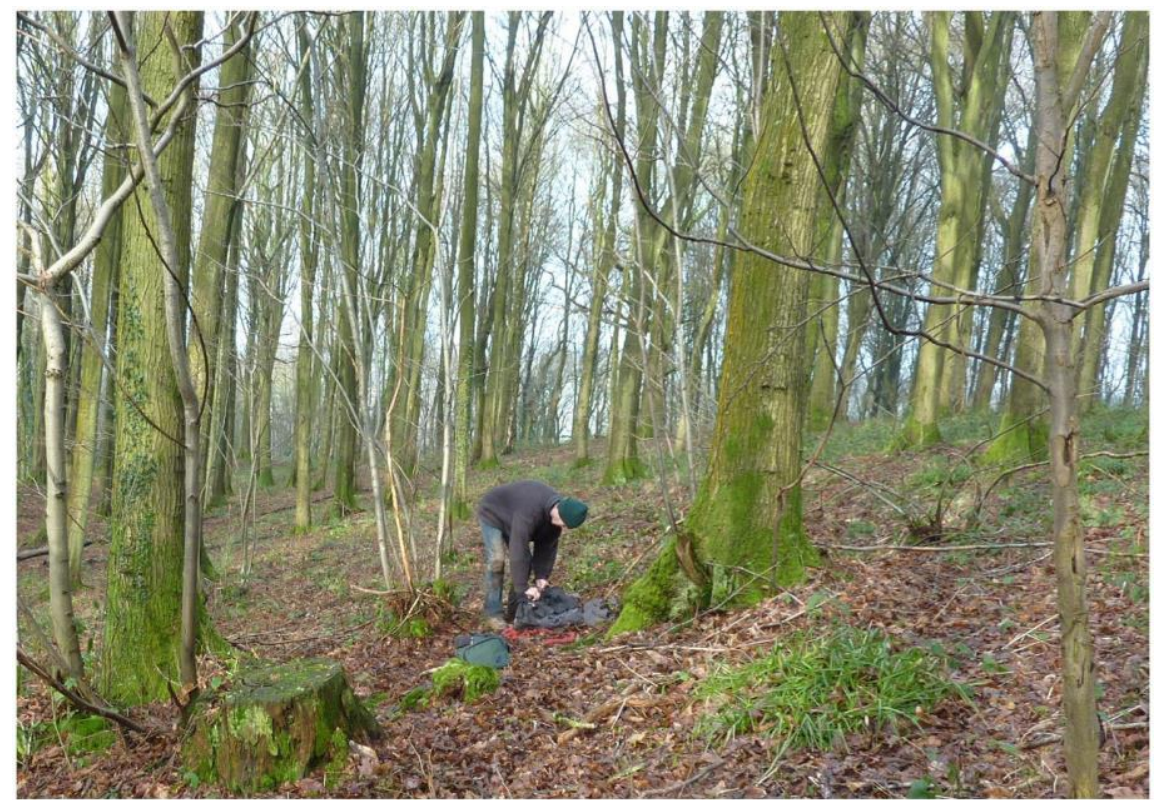

Figure 13. Welshbury Camp - coring tree GLWC01 (single stem grown from coppice stool, to right of the dendrochronologist). Image (c) Rob Jarman. 
this, as the tree occurs as a residual point below the regression curve, with a bigger girth for its age than would be anticipated.

\section{Discussion}

Eight sweet chestnut trees sampled from five sites in west and south Gloucestershire and south Herefordshire have provided seven cores and five radial sawn sections that have produced information on annual and seasonal growth characteristics, growth rates and tree ages. As the first systematic attempt to apply dendrochronological analysis to sweet chestnut trees in Britain, the results achieved here endorse the potential for dendrochronological analysis of sweet chestnut wood from living and dead trees of a range of ages and management histories.

\section{Dendrochronological potential of sweet chestnut indicated by this study}

There are two main results from this research warranting discussion: first, crossmatching of separate sweet chestnut trees was successful, both within and between sites; second, cross-matching of sweet chestnut with oak was successful, across a wide range of sites. There are several potential applications of the analysed results, to ancient living trees, mature timber trees, coppice wood and dead wood.

\section{Intra-specific cross-matching}

Sweet chestnut growth-ring series were successfully cross-matched between separate samples within the same site at three locations (Croft, Littledean Hall and Tortworth), so that a long combined time-series within each site could be produced. Furthermore, two of these series (Croft and Littledean Hall) also cross-matched between sites, indicating that differences in their environment and site history did not affect the inter-annual growth characteristics dependent, presumably, on regional climatic 
parameters. This intra-specific cross-matching, both within and between sites, reflects some European studies of sweet chestnut, where climate responsiveness resulting in synchronisation was observed (Cuenca et al., 2014; Mirchev et al., 2009). In contrast, Romagnoli et al. (2004) compared the dendrochronological behaviour of sweet chestnut trees in the same stand and found that intra-specific synchronisation was poor. They postulated that studying managed chestnut stands is problematic, as broad climate signals can be masked by short-term interventions such as coppicing.

For the chestnut trees sampled in the present study, there was no clear definition of juvenile, mature or senescent phases. This was unexpected, given the variety of ages of the trees sampled and also the variety of habitats (avenue tree, woodland tree or coppice stem). These observations of the growth characteristics of chestnut wood of various ages, parts of tree and growing environments may be informative for studies of chestnut timber where the original growing context has been lost. The observed relative thinness of chestnut bark cf. oak and the short phase, even as little as five years (cf. Fonti et al. 2006), of sapwood may assist estimation of missing rings. It is commonly recognised in forestry that sweet chestnut is a valuable wood because the sapwood is minor: it is the early onset of heartwood that makes sweet chestnut wood so durable especially as small roundwood, cf. oak where sapwood is a broader component of small roundwood.

The slowness of growth found in the two Tortworth branch stubs could aid attempts to date relatively small-dimensioned sweet chestnut wood samples, perhaps when analysing archaeological wood specimens where definition between Quercus and Castanea is often difficult. Sweet chestnut would usually be assumed to grow faster than oak, but this study shows how slowly sweet chestnut can grow. 
Further research including a wider geographical selection of samples will be needed to make definitive analyses of typical growth rates and to identify growth rate transformation thresholds. However, the data shown for cumulative ring widths (Figure 2) and decadal growth rates (Figure 3) indicate the underlying biological age growth trend for these sweet chestnut trees.

One outcome from this research with potential application to studies of veteran sweet chestnut trees is the measured girth-to-age relationship. Figure 4 shows the measured/calculated girths for each section plotted against the measured/calculated age of each section, producing a coefficient of determination $\mathrm{R}^{2}$ $=0.89$. These data indicate a potential girth:age relationship for sweet chestnut that could assist the dating of girth-measured sweet chestnut trees, although the small sample size and restricted geographical representation necessarily make this relationship provisional pending further sampling.

\section{Inter-specific cross-matching}

The sweet chestnut trees in this study have been cross-matched successfully with oak reference series from a range of sites in England and in Brittany (France). This outcome compares favourably with Romagnoli et al. (2004), who found that interspecific synchronisation of sweet chestnut with oak Quercus sp. (in central Italy) was successful between natural stands. Romagnoli et al. concluded that oak chronologies might be used to obtain absolute dating of sweet chestnut series from a geographical area similar to the oak. The successful cross-matching of the Croft and Littledean Hall chestnut series with oak from Brittany suggests that this chestnut:oak synchronisation can extend from England through to western France, at least. In that context, the present work indicates the possibility of a pan-European ability to cross-match sweet chestnut between separate sweet chestnut populations and also with oak populations. 


\section{Dendrochronological potential of sweet chestnut from different environments}

There are four environmental contexts from which sweet chestnut wood has been sampled in the present study: ancient living trees, mature timber trees, coppice trees and deadwood.

\section{Ancient living trees}

The presumption before the experiment with the Tortworth and Littledean Hall chestnut trees would have been that to core such old trees would be unproductive owing to rot, cavities and shake (Schweingruber, 1993, p. 181). The cores from the two Tortworth trees (from three limbs of the main tree and the trunk of the neighbouring tree) showed this to be partially true - two of the cores could not be assessed owing to the close-grown and contorted nature of their rings. However, the other two cores could be ring counted and measured and were cross-matched into a combined chronology spanning ninety-five years.

The main trunk of the ancient Tortworth Chestnut is hollow, so cannot be dated back to its origins; and its main limbs have collapsed and regrown during the past 200-300 years. This research has dated a regenerated stem from one of the collapsed boughs from this tree, providing a start date of AD 1820: this could indicate the approximate date of the bough collapse and might be able to be cross-referenced with one of the several landscape paintings that depict the Tortworth Chestnut at that period (cf. Strutt, 1830). The Tortworth neighbour tree was also dated, giving a start date of AD 1739. The perspective drawing of Tortworth Court by J. Kip dated AD 1712 (Atkyns, 1712) shows the ancient tree within a formal garden setting, but not this neighbouring tree, the site for which was then part of the outer garden. The calculated start date of AD 1739 thus concurs with this historical evidence. 
The successful coring of three ancient sweet chestnut trees at Littledean Hall, with two cores cross-matched into a 146-year site mean chronology that synchronised well with oak reference chronologies, indicates that large-dimension $(6 \mathrm{~m}$ and $8 \mathrm{~m}$ girth) ancient sweet chestnut trees can be successfully cored and measured. These trees did not display the anticipated problems of ring shake or hidden cavities although the cores were not taken through to the central pith, owing to the anticipated risk of meeting a cavity/rot pocket.

\section{Mature timber trees}

The mature chestnut tree ( $2.75 \mathrm{~m}$ girth) sampled in Chestnuts Wood yielded a good measureable core: the borer went through to the pith and no shake or cavities were encountered. Of especial significance is the cross-matching of this sweet chestnut timber (with $\sim 100$ growth rings) with a range of oak reference series. This agrees with the findings of Mirchev et al. (2009), who undertook a dendrochronological investigation of sweet chestnut in SW Bulgaria, coring living trees and devising a radial growth index for sweet chestnut from sixty tree ring chronologies that they cross-dated against oak Quercus frainetto stands.

\section{Coppice grown trees}

The coppice-grown stem (1.7 m girth) sampled in Welshbury Wood yielded a good core, but even with sixty-three growth rings it was not cross-matched with any other sweet chestnut or oak reference series. The successful age determination of this coppice tree does, however, inform the management history of this wood by indicating that the last coppice cut was in AD 1940. The failure to cross-match this tree is most likely a result of insufficient samples, management disturbances and a relatively short series of rings. However, Fonti et al. (2006) successfully analysed 
sweet chestnut tree rings to assess competition in abandoned chestnut coppices (age $=$ 60 ) in south Switzerland, suggesting that research into dating trees with relatively few growth rings would be worthwhile.

\section{Deadwood resources}

The Croft study represents a very significant outcome of the present research. The discovery of the long-dead chestnut tree in the Croft Castle parkland gave a rare opportunity to sample a nationally significant feature. The National Trust (owner and manager of the Croft Castle estate) does not normally allow potentially damaging interventions in historic landscapes, but supported this experiment because the history of the Croft landscape is presently being investigated (Gallagher, 2015) and no analysis of tree rings had been undertaken.

The method for extracting the sawn sections from the fallen Croft chestnut tree proved straightforward, principally because the tree was structurally sound and at no risk of movement once cutting commenced. The position of the tree adjacent to its stump meant that the original context of the tree was evident: it was possible to reconfigure the standing tree's original topography of trunk and boughs and relate it to ring growth patterns.

The Croft tree was remarkable for its well-preserved wood and the extent of the unbroken growth-ring sequence in a single section: the longest sawn radial section that was ring counted was $1.28 \mathrm{~m}$ length with 234 consecutive rings uninterrupted by shake or rot (Figure 6). Given the 34 years of lying dead in open woodland, the internal structure of the trunk almost to the outer surface was surprisingly undecayed, apart from the core where $\sim 50$ years of growth had rotted out, probably when the tree had been standing. The section cut from higher up the trunk $(3.8 \mathrm{~m})$ provided an entire ring sequence from sapwood to pith, that cross-matched with the lower trunk 
section and thereby provided some of the rings to the pith missing from the lower rotted-out section: sampling hollow trees at higher elevations to recover sound timber can provide invaluable ring sequences. The growth-ring consistency throughout the 260 years of surviving rings, showing little sign of shake, neither ring nor star, justifies future attempts to sample sections of similar antiquity from historic sites elsewhere.

Of especial value was the knowledge preserved for this Croft tree - in particular to know definitively from the feller of the tree that the cutting date was AD 1981. This enabled a cross-check of the growth-ring analysis - a known end date for the ring sections confirming a cross-match with oak reference series.

The Croft example highlights the potential to extract sections from long-dead sweet chestnut trees and extend the regional and chronological history of sweet chestnut. The same potential presumably exists for even longer-dead timbers within preserved structures, such as archaeological sites or ancient buildings. For example, Čufar et al. (2014) examined building timbers from the historic Pišece castle in Slovenia: they were able to dendroprovenance oak timbers (dating from AD 15151697) to local woodland sources, but not the sweet chestnut timbers (dating from AD 1758) owing to inadequate sweet chestnut chronologies. However, the sweet chestnut timbers were dated using absolute chronologies for oak, silver fir and beech, obtaining $t$-values $>4$.

\section{Implications for conservation of veteran trees and deadwood}

This study indicates the potential for dendrochronological analysis of sweet chestnut trees to inform arboriculturalists, foresters, and estate and woodland managers on the cultural and biological significance of sweet chestnut trees in their care. Many historic 
sites with veteran trees have within them 'deadwood graveyards' containing fallen timber and cut-down hulks, either in situ or relocated a short distance from elsewhere on the site. The Croft example highlights the merits of recovering large deadwood sections from such sites to provide long sequences of growth rings, invaluable for historic landscape assessments. The original location and growth environment of recovered sections would need to be known for a meaningful assessment.

The success of the Croft deadwood assessment also raises the possibility of sampling upstanding living trees that have accessible deadwood sections. Such deadwood could provide ring sequences to substitute for unmeasurable or rotted wood. The sampling would need to be sensitive to tree health and safety interests and also respect the important deadwood-dependent fauna and flora in veteran tree habitats (Alexander, Green, \& Morris, 2016; Green, Alexander, \& Key, 1999).

Deadwood resources have been shown here to provide valuable information for growth-ring analysis: this may avoid the need to core living trees. Shigo (1984) set out the fundamental biology of tree response to wounding and demonstrated how it mitigates against damage from coring, but tree-coring is perceived to create a risk of fungal or pest infiltration. Grissino-Mayer (2003) and Tsen, Sitzia and Webber (2016) inter alia have assessed the impacts of tree coring and concluded that any risk is low and is manageable. There are continuing discussions on the pros and cons of coring and whilst coring could be applied very selectively and carefully to survey sweet chestnut trees, to establish a representative (geographical and typological) series of reference chronologies, we identify here that taking sections from dead elements of standing or fallen veteran trees can be a useful alternative to coring living wood (subject to conserving deadwood-dependent flora and fauna and cultural heritage interests). 


\section{Implications for dendroarchaeology}

This study has not examined any archaeological wood or historic construction timber specimens, but there appears to be potential, theoretically at least, to date sweet chestnut wood specimens by cross-matching with oak reference chronologies. There are only a few artefacts of sweet chestnut wood that have been recorded archaeologically in Britain, such as the Roman chisel handle described in Watson (1985) and the Roman writing tablet reported in Watson (1987), and none appears to contain the $\geq 50$ rings conventionally required for dendrochronological dating (Historic England, 1998).

Dominguez-Delmas et al. (2015) described dendroarchaeological studies in the Iberian Peninsula, relating tree ring analysis to cultural heritage. They stated the need to develop master chronologies for specific tree species, so that ancient timbers can be dated, but only one longer-term chronology (pre-AD 1800) for sweet chestnut was noted.

The present research may make a small contribution to the development of a dendrochronological reference series for sweet chestnut Castanea sativa.

Geolocation Information: awaiting doi allocation

Acknowledgments

This research was assisted by Tree-Ring Services in support of a $\mathrm{PhD}$ student at the University of Gloucestershire researching the history and origins of sweet chestnut in Britain. Permission for access and assistance with the project was provided by the owners of the sites: National Trust, Forestry Commission, Tortworth Estates (Robert Moreton), James Dickens. Matthew Smith cut the sections for us at Croft Castle. We acknowledge contributions of information, comment and analysis from Jill Butler, Iain Carter, Marco Conedera, Ted Green, Zoe Hazell, Patrik Krebs, Brian Muelaner, Les Rogers, David Rossney, Ian Tyers and two independent anonymous reviewers. 


\section{References}

Agin, B. (2011). A dendrochronological and dendroclimatological analysis on modern oak (Quercus spp.) trees in Happy Valley, Hedgerley Park and Langley Park, England. Unpublished MSc, Brunel University.

Alexander, K., Green, T., \& Morris, R. (2016). Naturalised broadleaf trees - a call for a strategic reappraisal. British Wildlife, 28(1), 13-20.

Atkyns, Sir R. (1712). The Ancient and Present State of Gloucestershire. First edition. London.

Arnold, A. J., Howard, R. E., Laxton, R. R., \& Litton, C. D. (2003). Tree-Ring Analysis of timbers from Cobham Hall, Cobham, Kent (AML Report 50/2003). Historic England, Centre for Archaeology.

Baillie, M. G. L. (1982). Tree-ring dating and archaeology. London: Croom-Helm.

Baillie, M. G. L., \& Pilcher, J. R. (1982). A master tree-ring chronology for England. Unpublished computer file ENGLAND. Queen's University, Belfast.

Barefoot, A. C. (1975). A Winchester dendrochronology for AD 1635-1972 - its validity and possible extension. Journal of the Institute of Wood Science, 7(1), 25-32. 
Braden, N., \& Russell, K. (2001). Chestnut in the United Kingdom: forest area, management and utilisation as timber. Forest, Snow and Landscape Research, 76(3), 505-510.

Briffa, K. R., Wigley, T. M. L., Jones, P., Pilcher, J. R., \& Hughes, M. K. (1986). The reconstruction of past circulation patterns over Europe using tree-ring data. Final report to the Commission of European Communities, Contract CL.111.UK(H).

Buckley, P., \& Howell, R. (2004). The ecological impact of sweet chestnut coppice silviculture on former ancient broadleaved woodland sites in South-east England (Research Report No. 627). English Nature.

Conedera, M., Krebs, P., Tinner, W., Pradella, M., \& Torriani, D. (2004). The cultivation of Castanea sativa (Mill.) in Europe, from its origin to its diffusion on a continental scale. Vegetation History \& Archaeobotany, 13, 161-179. DOI: 10.1007/s00334-004-0038-7.

Cuenca, J., Schneider, L., Konter, O., Düthorn, E., Esper, J., \& Patón, D. (2014). Dendrochronological comparison of Castanea sativa Mill. and Quercus pyrenaica Willd. in southwest Spain. TRACE, 12, 40-45. http://doi.org/10.2312/GFZ.b10314055.

Čufar, K., Bizjak, M., Kuzman, M. K., Merela, M., Grabner, M., \& Brus, R. (2014). Castle Pišece, Slovenia - Building history and wood economy revealed by 
dendrochronology, dendroprovenancing and historical sources. Dendrochronologia, 32(4), 357-363. http://dx.doi.org/10.1016/j.dendro.2014.08.002.

Domínguez-Delmas, M., Alejano-Monge, R., Van Daalen, S., Rodríguez-Trobajo, E., García-Gonzalez, I., Susperregi, J., ... Jansma, E. (2015). Tree-rings, forest history and cultural heritage: current state and future prospects of dendroarchaeology in the Iberian Peninsula. Journal of Archaeological Science, 57, 180-196.

http://dx.doi.org/10.1016/j.jas.2015.02.011.

Ducarel, A. (1771). Concerning chestnut trees. Phil. Trans. Roy. Soc., 61, 136.

Evelyn, J. (1706). Silva, or A Discourse of Forest-Trees and the Propagation of Timber in His Majesty's Dominions. Fourth Edition. London: Royal Society.

Fonti, P., Cherubini, P., Rigling, A., Weber, P., \& Biging, G. (2006). Tree rings show competition dynamics in abandoned Castanea sativa coppices after land-use changes. Journal of Vegetation Science, 17, 103-112.

Gallagher, C. (2015). Croft Castle, Herefordshire: landscape analysis. National Trust.

Godwin, H. (1975). The History of the British Flora. Cambridge: CUP.

Green, T., Alexander, K., \& Key, R. (1999). Managing Our Ancient Trees. http://www.treecouncil.org.uk/tnews/ancient.htm 
Grissino-Mayer, H. D. (1993). An updated list of species used in tree-ring research. Tree-ring Bulletin, 53, 17-43.

Grissino-Mayer, H. D. (2003). A manual and tutorial for the proper use of an increment borer. Tree-Ring Research, 59(2), 63-79.

Groves, C. (1993). Tree-ring analysis of a wood assemblage from Tilbury Fort, Essex 1988-89 (AML Report No. 20/93). England: HBMCE.

Guibal, F. R. (1987). Dendrochronology of oak in Brittany. Dendrochronologia, 5, $69-77$.

Hillam, J. (1985). Tree-ring analysis of timbers from Norwich: Courts site, 1981 (AML Report 4554). England: HBMCE.

Historic England. (1998). Dendrochronology: guidelines on producing and interpreting dendrochronological dates. London: Historic England.

Howard, R. E., Laxton, R. R., \& Litton, C. D. (2000). Tree-ring analysis of the timbers from the buildings and living trees at Stoneleigh Abbey, Stoneleigh, Warwickshire (AML Report No. 80/2000). Historic England: Centre for Archaeology. Huntley, B., \& Birks, H. J. B. (1983). An Atlas of Past and Present Pollen Maps for Europe: 0-13,000 years ago. Cambridge: CUP. 
Krebs, P., Conedera, M., Pradella, M., Torriani, D., Felber, M., \& Tinner, W. (2004).

Quaternary refugia of the sweet chestnut (Castanea sativa Mill.): an extended palynological approach. Vegetation History and Archaeobotany, 13, 145-160. DOI: 10.1007/s00334-004-0041-z.

Laxton, R. R., \& Litton, C. D. (1988). An East Midlands master tree-ring chronology and its use for dating vernacular buildings. Monograph Series, 3. University of Nottingham, Department of Classical and Archaeological Studies.

Mattioni, C., Martin M. A., Pollegioni, P., Cherubini, M., \& Villani, F. (2013). Microsatellite markers reveal a strong geographical structure in European populations of Castanea sativa (Fagaceae): evidence for multiple glacial refugia. American Journal of Botany, 100(5), 951-961. doi: 10.3732/ajb.1200194

Mirchev, St., Lyubenova, M., Dimitrova, V., \& Bratanova-Doncheva, S. (2009). Dendrochronological investigation on Castanea sativa Mill. in Belasitza Mountain and western Balkans (Berkovitza Mountain). Biotechnology \& Biotechnological Equipment, 23(sup1), 377-380. doi: 10.1080/13102818.2009.10818443

Moir, A. K. (1996). A dendrochronological analysis of 9 oak compartments from the Sotterley Estate, Suffolk, England: an interim report. Unpublished.

Moir, A. K. (2012a). Dendrochronological analysis of a section of modern oak timbers from Yeo Meads, High Street, Congresbury, Somerset, England (Dendro Report BSWR/21/12). Tree-Ring Services. 
Moir, A. K. (2012b). Dendrochronological analysis of oak timbers from Tuns Farm House, Huntley, Gloucestershire, England (Dendro Report GLTF/19/12). Tree-Ring Services.

Moir, A. K. (2012c). Dendrochronological analysis of oak trees at Lullingstone Country Park, Eynsford, Kent, England (Dendro Report BRLL/01/12). Tree-Ring Services.

Moir, A. K. (2012d). Dendrochronological analysis of three oak trees at the National Trust's Lodge Park Estate, Aldsworth, Gloucestershire, England (Dendro Report GLLP/23/12). Tree-Ring Services.

Moir, A. K. (2014). Dendrochronological analysis of oak trees at the Horsepool Bottom Nature Reserve, Jubilee Road, Mitcheldean, Gloucestershire, England (Dendro Report GLOR/20/14). Tree-Ring Services.

MOLA. (2011). Alverstone Marshes, Isle of Wight - an assessment of the timbers recovered from archaeological excavations at Alverstone. London: Museum of London Archaeology.

Nayling, N. (1991). An identification of sweet chestnut Castanea sativa from Roman London. WARP, 10, 12.

Pilcher, J. R., \& Baillie, M. G. L. (1980). Eight modern oak chronologies from England and Scotland. Tree-ring Bulletin, 40, 45-58. 
Preston, C. D., Pearman, D. A., \& Dines, T. D. (Eds). (2002). New Atlas of the British and Irish Flora. Oxford: Oxford University Press.

Rackham, O. (2006). Woodlands. London: New Naturalist, Collins.

Reid, C. (1899). The origin of the British flora. London.

Romagnoli, M., Nocetti, M., Sarlatto, M., \& Evangelistella, L. (2004).

Dendrochronological assessment of chestnut (Castanea sativa Mill.) for dating purposes in Central Italy. Dendrochronologia, 21(3), 117-130.

Schweingruber, F. H. (1993). Trees and Wood in Dendrochronology. Berlin Heidelberg: Springer-Verlag.

Shigo, A. L. (1984). Compartmentalization: a conceptual framework for understanding how trees grow and defend themselves. Annual Review of Phytopathology, 22, 189-214.

Siebenlist-Kerner, V. (1978). The chronology, 1341-1636, for certain hillside oaks from Western England and Wales. In J. M. Fletcher (Ed.). Dendrochronology in Europe (pp. 295-301). Oxford: BAR Int. Ser., 51.

Spina, S., \& Romagnoli, M. (2010). Characterization of ring shake defect in chestnut (Castanea sativa Mill.) wood in the Lazio Region (Italy). Forestry, 83(3), 315-327. doi:10.1093/forestry/cpq014. 
Squatriti, P. (2013). Landscape and change in early medieval Italy: chestnuts, economy and culture. New York: CUP.

Stace, C. A., \& Crawley, M. J. (2015). Alien plants. London: Harper Collins.

Strutt, J. G. (1830). Sylva Britannica: or, Portraits of Forest Trees distinguished For Their Antiquity, Magnitude, or Beauty. London.

Telewski, F. W., \& Lynch, A. M. (1991). Measuring growth and development of stems. In J. P. Lassoie \& T. M. Hinckley (Eds.). Techniques and Approaches in Forest Tree Ecophysiology (pp. 503-555). Boca Raton: CRC Press.

Tsen, E. W. J., Sitzia, T., \& Webber, B. L. (2016). To core, or not to core: the impact of coring on tree health and a best-practice framework for collecting dendrochronological information from living trees. Biol. Rev., 91, 899-924. doi: 10.1111/brv.12200.

Tyers, I. (1999). Dendro for Windows Program Guide 2nd Edition. ARCUS Rep, 500.

Villalba, R., \& Veblen, T. T. (1997). Determination of total tree ages using increment core samples. Ecoscience, 4, 534-42. 
Watson, J. (1985). Identification of mineral preserved wood associated with iron objects from Housesteads, Hadrian's Wall (Report No. 4546). Ancient Monuments Laboratory. English Heritage.

Watson, J. (1987). Mineral preserved organic material from the Corbridge hoard (Report No. 158/87). Ancient Monuments Laboratory. English Heritage.

White, J. E. J. (1998). Estimating the age of large and veteran trees in Britain. Information Note FCIN12. Forestry Commission.

Woodland Trust. (2016). Ancient Tree Inventory. Retrieved May, 2016, from the ATI database. http://www.ancient-tree-hunt.org.uk/project. 
List of Tables, with required titles

Table 1. Summary of dendrochronological analysis of seven cores and five sawn sections from eight sweet chestnut trees in western England.

Table 2. Cross-matching $t$-values between growth ring series from three radial sections sawn from the Croft Castle sweet chestnut tree HRCC01.

Table 3. Cross-matching of HRCC01 against oak reference chronologies for England and Brittany (France).

Table 4. Cross-matching of LDEAN-2 against the HRCC01 chestnut chronology and oak reference chronologies from England and Brittany (France).

Table 5. Cross-matching of GLCW01 (sweet chestnut) against oak reference chronologies. 
List of Figures, with required captions

Figure 1. Map of the sampled sites in western England, in their European context

Figure 1. Caption note: ‘C Crown Copyright and Database Right [2016]. Ordnance Survey (Digimap Licence). Contains public sector information licensed under the Open Government Licence v3.0.’

Figure 2. Cumulative growth-ring widths plotted for the five cross-matched sweet chestnut trees

Figure 3. Decadal growth rates for each measured sequence and the two combined series from the five cross-matched sweet chestnut trees

Figure 4. Regression analysis of girth against age for the five sweet chestnut trees

Figure 4. Caption note:

In Figure 4 the measured girths at each tree section have been plotted against the measured/estimated age of each section. The type of tree for each section has been noted, so that residual values might be interpreted:

$\times \quad$ branch stub

O coppice regrowth stem

- veteran parkland tree

$\checkmark \quad$ ancient avenue tree

- woodland standard tree

$+\quad$ regeneration from collapsed ancient tree

Figure 5. Croft Castle chestnut tree - location of sawn sections HRCC01 \& HRCC02

Figure 6. Croft - sawn sections HRCC01 \& HRCC02

Figure 7. Croft - sawn section HRCC03 
Figure 8. Littledean Hall - coring tree GLLH01

Figure 9. Chestnuts Wood - coring tree GLCW01

Figure 10. Tortworth - coring tree GLTO01

Figure 11. Tortworth - sawn section from stub end GLTO05

Figure 12. Tortworth - coring tree GLTO06

Figure 13. Welshbury Camp - coring tree GLWC01 (single stem grown from coppice stool, to right of the dendrochronologist) 